\title{
MEMAHAMI MASLAHAT MENGGUNAKAN PENDEKATAN FILSAFAT UTILITARIANISME MENURUT MUHAMMAD ABU ZAHRAH
}

\author{
Abdul Basith Junaidy \\ Universitas Islam Negeri Sunan Ampel Surabaya, Indonesia \\ E-mail: basithjunaidy63@gmail.com
}

\begin{abstract}
This paper seeks to describe the efforts of Abû Zahrah in making the philosophy of utilitarianism as a means of understanding the concept of maslahah mursalah in legal reasoning. In Zahrah's view, the principle of utilitarianism can be taken into account as a guide to understand and apply the concept of maslahah. Zahrah goes on to argue that maslahah can be applied quantitatively using the hedonic calculus as a tool of measurement. Zahrah defines maslahah as an action that is valued as having the greatest benefit for the majority of people in the long term. In his opinion, there are seven factors that determine the level of satisfaction and pain resulted from an action, namely intensity, duration, certainty, propinquity, fecundity, purity, and extent. The calculation will produce positive balance if the credit (satisfaction) is much greater than the debt (pain). This calculus, according to Zahrah, can be applied to measure the benefit and loss in the discourses of maslahah mursalah.
\end{abstract}

Keywords: Maslạ̣ah mursalah, legal reasoning, utilitiranism.

\section{Pendahuluan}

Pada abad ke-11 H./ke-17 M. muncul sejumlah persoalan hukum baru yang penting bagi kehidupan ekonomi dan sosial dalam kesultanan Uthmânîyah. Masalah-masalah tersebut telah ditangani oleh fuqabâ yang tidak dikenal sebagai mujtabid, namun dapat diselesaikan melalui penalaran hukum yang didasarkan pada otoritas teks suci dan konklusi analogis tanpa keraguan sedikitpun. Akan tetapi bentuk penyelesaian masalah yang dilakukan oleh seorang Muslim yang bukan mujtabid banyak menuai kritik dari beberapa fuqahâ lainnya. Karena menurut mereka, ijtihâd hanya bisa dilakukan oleh para pendiri mazhab saja. Kritikan ini justru direspons balik dari para pembela ijtihâd di abad ke-13 H./ke-18 M. Kritik tersebut tidak hanya ditujukan 
kepada orang-orang yang mengklaim bahwa para mujtabid telah habis dan bahwa pintu ijtihâd telah tertutup, tetapi juga terhadap esensi taqlid yang telah mengakar di masyarakat. Yang paling menonjol di antaranya adalah Shah Walî Allâh al-Dahlawî (w.1176 /1762), Șan'âni (w.1182/1768), Muḥammad b. 'Abd al-Wahhâb (w.1202/1787), Ibn Ma'mar (w.1225/1810), dan Ibn 'Alî al-Sanûsî (w.1313/1895). ${ }^{1}$

Pada abad ke-19 Masehi, beberapa tokoh pembaru menyadari bahwa salah satu sebab dari kemunduran Islam adalah anggapan bahwa pintu ijtihâd telah tertutup. Mereka bersikeras menegaskan bahwa penutupan ijtihâd tidak pernah ada dan tak ada orang yang berhak menutupnya. Hal itu pernah diungkapkan oleh Rifâ'ah Râfi' alTahțâwî (w.1873 M) di Mesir pada pertengahan pertama abad ke-19 M. dan kemudian secara tegas diungkap oleh Jamâl al-Dîn al-Afghânî (w. 1897 M), Muḥammad 'Abduh (w. 1905 M), Aḥmad Khân (w.1898 M) dan lain-lain pada pertengahan abad ke-19 Masehi. ${ }^{2}$

Pada abad ke-20 Masehi telah umum diakui bahwa pintu ijtihâd tidak tertutup. Salah seorang pembaru Islam abad keduapuluh Masehi adalah shaykh Muhammad Abû Zahrah (1898-1974 M), seorang ulama besar Mesir dan seorang ahli hukum Islam terkemuka di dunia. Abû Zahrah menegaskan bahwa tak seorang pun berhak menutup pintu ijtihâd yang telah dibukakan Allah bagi akal manusia. Jika ada yang menyatakan demikian, pasti ia tidak memiliki dalil yang menjadi pijakan dan penutupan itu menjauhkan umat manusia dari al-Qur-ân, Sunnah dan athar ulama salaf yang saleh. ${ }^{3}$

Dalam berijtihad Abû Zahrah memerlukan metode ijtihâd, maka untuk keperluan tersebut, ia kemudian menulis kitab Ușull al-Fiqh. Dalam karyanya, Abû Zahrah mengemukakan cara-cara istinbât hukum melalui sumber-sumbernya. Untuk ber-istinbât, seseorang harus memenuhi seperangkat kualifikasi pengetahuan yang komprehensif tentang substansi materi sumber-sumber hukum dan perangkat yang dipakai sebagai penunjangnya. ${ }^{4}$

Karya Abû Zahrah ini berbeda dengan karya sejenis sebelumnya. Dalam menulis kitab ini, Abû Zahrah meliberasi dari segala ikatan

${ }^{1}$ Wael. B. Hallaq, Was The Gate of Ijtihad Closed? (New York: International of Middle East Studies, 16, I, (1994), 32.

${ }^{2}$ Harun Nasution, Islam Rasional (Bandung: Mizan, 2000), 19.

3 Muhammad Abû Zahrah, Târîkh al-Madhâbib al-Islâmîyah (Kairo: Dâr al-Fikr al'Arabî, 2009), 343.

${ }^{4}$ Muḥammad Abû Zahrah, Uṣ̂l al-Figh (Kairo: Dâr al-Fikr al-'Arabî, t.th.), 341-342. 
mazhab. Ia menampilkan suatu paradigma Ușûl al-Fiqh lintas mazhab dengan metode komparatif. Pendapat para ahli usû́l (usûliyyûn) dikemukakan lengkap dengan ragam argumentasi normatif berbasis alQur-ân, Sunnah, maupun bujjah-bujjah aqlìyah. Kemudian ia mengomparasikan pendapat, komentar, dan kritik para ulama terhadap berbagai masalah, serta mengurai lebih kelebihan maupun kelemahan masing-masing pendapat. Akhirnya, ia melakukan tariخ dan menetapkan salah satu pendapat yang ia dukung dengan argumentasi yang universal dan komprehensif. Tarjî̆ yang dilakukannya merupakan hasil pemikiran orisinalnya.

\section{Sketsa Biografis Muhạmmad Abû Zahrah}

Nama asli Muhammad Abû Zahrah adalah Muhammad b. Aḥmad b. Muṣtafâ b. Aḥmad b. 'Abd Allâh. Ia dilahirkan pada tahun $1316 \mathrm{H}$ atau bulan Maret tahun $1898 \mathrm{M}$ di al-Maḥallâ al-Kubrâ. ${ }^{5}$ Abû Zahrah memulai menimba ilmu di Kuttâb (Madrasah Dînîyah di serambi Masjid) dan Madrasah Awwalîyah (sekolah dasar). Di sini, ia mempelajari dasar-dasar ilmu membaca dan menulis. Kemudian ia melanjutkan ke sekolah menengah. Di sekolah ini, ia menyempurnakan hapalan al-Qur'ân dan pelajaran ilmu-ilmu modern seperti matematika, geografi di samping ilmu-ilmu bahasa Arab. Sekolah-sekolah menengah pada saat itu merupakan tahap pembelajaran yang menentukan jenjang-jenjang pendidikan berikutnya. Pada tahun 1913 M, Abû Zahrah memasuki Universitas al-Aḥmadî di Tanțâ dan kuliah di sana selama tiga tahun, karena ia kemudian melanjutkan ke Perguruan Tinggi Hakim Agama (alMadrasah al-Qadâ' al-Shar $(\hat{\imath}){ }^{6}$

Pada tahun 1916, Abû Zahrah memasuki Perguruan Tinggi Hakim Agama (Madrasah al-Qadâ' al-Shar'í) ${ }^{7}$ setelah melalui persaingan yang ketat untuk mengikuti ujian masuk perguruan tinggi tersebut. ${ }^{8}$

5 Abû Bakr 'Abd al-Razzâq, Abû Zabrah Imâm 'Așrib: Hayâtuh wa 'Atharuh al-Tlmî (Kairo: Dâr al-I'tiṣâm, 1984), 24.

6 'Abd al-Razzâq, Abû Zabrah, 26.

${ }^{7}$ Sekolah Tinggi ini didirikan atas prakarsa shaykh Muhammad 'Abduh. Namun ada jarak antara prakarsa awal dan pembentukannya, sampai prakarsa itu diwujudkan oleh muridnya Sa'ad Zaghlûl Bâshâ selaku Menteri Pendidikan. Ia menempuh pendidikan di sini selama sembilan tahun. Ibid., 28.

8 Sekolah Tinggi ini didirikan pada tahun 25 Februari 1907 dengan tujuan menghasilkan ulama yang dipromosikan menduduki jabatan hakim di lembaga, mufti, pengacara di lembaga peradilan sharî‘ah dan lain-lain. Input-nya diambil para 
Menurut Harun Nasution, pendirian perguruan tinggi ini merupakan salah satu bagian dari pembaruan dalam institusi hukum di Mesir yang ditujukan untuk memberikan pendidikan modern bagi calon hakim agama. ${ }^{9}$ Pembentukan integritas keilmuan dan keluasan wawasannya terbentuk dan menjadi sempurna di lembaga pendidikan ini.

Abû Zahrah sendiri lulus dari Perguruan Tinggi Hakim Agama pada tahun 1925. Bila doktor Aḥmad Amîn adalah lulusan pertamanya, maka Abû Zahrah adalah lulusan terakhirnya. Ia kemudian bekerja magang sebagai pengacara selama satu tahun. Selanjutnya ia meneruskan pendidikan dengan mengambil program diploma penyetaraan sertifikat mengajar di Universitas Dâr al-'Ulûm selama satu tahun dan lulus pada tahun 1927. Pada tahun yang sama, ia diangkat sebagai dosen dengan mata kuliah hukum Islam, tafsir, ilmu-ilmu keagamaan, dan Bahasa Arab pada Sekolah Persiapan Universitas Dâr al-'Ulûm selama satu tahun mulai 10 Oktober 1927 M sampai 14 November $1928 \mathrm{M}$ di samping tetap mengajar di almamaternya, Perguruan Tinggi Hakim Agama. Namun ia tetap terus mengajar di Sekolah Persiapan tersebut sampai tahun 1930 M. Kemudian ia berpindah untuk mengajar di sekolah-sekolah menengah umum al-Thanâwî al-Am selama 2 tahun 6 bulan setelah dibubarkannya Sekolah Persiapan sampai tahun 1932. Ketika terjadi program pertukaran dosen antara Kementerian Pendidikan (Wizâarat al-Ma'ârif) dan Lembaga Pendidikan Agama (Idârat al-Ma âbid al-Dinîyah) pada awal Januari tahun 1933, Abû Zahrah pindah ke Fakultas Ushuluddin Universitas al-Azhar untuk mengajar matakuliah al-jadal wa al-Khitâbah (debat dan retorika), Sejarah Agama-agama, dan Keyakinan dan Aliran Kepercayaan pada Program Studi Penyiaran Agama Islam (Qism al-

lulusan pilihan baik dari al-Azhâr maupun Dâr al-'Ulûm. Namun, Al-Azhâr mengajukan tuntutan pada pemerintah agar sekolah ini dan Dâr al-'Ulûm dibubarkan, sebab mayoritas mahasiswanya tinggal sedikit karena ada dua lembaga pendidikan spesialis pada saat itu, yaitu Institut Peradilan Sharî‘ah yang memokuskan diri untuk mengkasilkan spesialis di bidang hukum Islam yang akan berkiprah menjadi hakim dan mufti di lingkungan Lembaga Peradilan Shariah dan Universitas Dâr al-'Ulûm yang memokuskan diri untuk menghasilkan para guru bahasa Arab dan guru agama Islam di sekolah dasar dan menengah. Namun, pemerintah setuju dengan pembubaran Institut Peradilan Sharî‘ah dan tidak setuju dengan pembubaran Dâr al-'Ulûm. Nâșir Maḥmûd Waḥdân, Abûu Zahrah 'Âliman Islâmiyyan (Kairo: Dâr al-Ḥaram li-al-Turâth, 2012), 60-61.

9 Harun Nasution, Pembaharuan dalam Islam Islam: Sejarah Pemikiran dan Gerakan (Jakarta: Bulan Bintang, 1975), 82-83. 
Wa za wa al-Irshâd). Di sini, ia menelorkan beberapa karya, antara lain: al-Khitâbah, Târîkh al-Jadal, Târîkh al-Diyânât al-Qadîmah, dan Muhẩdarât fì al-Nașânŷab yang telah dialihbahasakan ke dalam berbagai bahasa asing. ${ }^{10}$

Karirnya secara akademik terus menanjak di Fakultas Hukum mulai dari sebagai mudarris (dosen biasa), lalu menjadi ustâdh musâid (asisten profesor), kemudian menjadi ustâdh (guru besar) yang memiliki jabatan sampai dengan Ketua Program Studi Sharî‘ah sampai ia memasuki usia pensiun pada tahun 1958. Meski sudah pensiun, ia tetap mengajar di Fakultas Hukum sampai terbitnya instruksi dari penguasa kepada Fakultas Hukum dan Universitas Dâr al-'Ulûm agar melarang Abû Zahrah untuk mengajar di Fakultas Hukum. ${ }^{11}$ Namun semua itu tidak menyurutkan semangatnya untuk terus melangkah menyebarkan dan menyatakan pikiran-pikirannya secara kritis mengenai problem-problem umum yang penting yang dihadapi umat meskipun pandangannya berseberangan dengan penguasa. ${ }^{12}$

\section{Maslahah Perspektif Filsafat Utilitarianisme}

Dalam menjelaskan arti maslạ̣ah, Abû Zahrah seringkali mengutip pendapat dua filsuf etika Barat terkemuka, Jeremy Bentham dan John Stuart Mill. Buku Mill yang berjudul Utilitarianism telah diterjemahkan ke dalam bahasa Arab dengan judul Risâlat al-Manfa'ab oleh Muḥammad 'Âtiff Barakât. Sedangkan buku Bentham yang berjudul An Introduction to the Principles of Morals and Legislations diterjemahkan ke dalam bahasa Arab dengan judul Ușull al-Sharâi` oleh Fatḥ Zaghlûl. Ia mengutip pendapat Bentham yang mengatakan bahwa tujuan tertinggi etika dan aturan perundangan adalah sama, yaitu demi kebahagiaan manusia. Bedanya, etika berkaitan dengan kebahagiaan individu dan pendidikan jiwanya tanpa adanya sanksi, sedangkan aturan perundangan mengatur hubungan antar-manusia terkait dengan

${ }^{10}$ Waḥdân, Abûu Zabrah 'Âliman, 68-70.

11 Hal itu disebabkan pandangannya yang cukup kritis terhadap kebijakan pemerintah presiden Jamâl 'Abd al-Nâșir. Abû Zahrah mengritik ideologi sosialisme, pembatasan kelahiran dan pembatasan perceraian. Selama pencekalan, Abû Zahrah menulis dua karya besar, yaitu al-Mưjizah al-Kubrâ dan Khâtam alNabiyyin. Setelah terbit surat pencabutan pencekalan, bukan berarti persoalannya selesai. Khâtam al-Nabiyyîn, kitab yang baru diterbitkan, kemudian dicekal oleh pemerintah pengganti al-Nâșir, yaitu presiden Anwar al-Sâdât, karena sebagian isinya yang bertentangan dengan kebijakan pemerintah. Wahdân, Ab̂u Zahrah 'Aliman, 87-90.

${ }^{12}$ Ibid., $10-11$. 
lembaga peradilan dengan menggunakan hukum-hukum material dan formal yang di dalamnya ada ketentuan sanksi bagi yang melanggarnya. Sanksi ini bersifat duniawi, tidak ukhrawî. Atas dasar itu, etika tidak bisa dilepaskan dari politik maupun aturan perundangan. Tidak bisa dikatakan bahwa masalah ini buruk dari sisi etika, akan tetapi baik dari sudut pandang politik atau aturan perundangan. Sebagaimana tidak boleh dikatakan bahwa asas-asas matematika benar pada situasi tertentu dan tidak benar pada situasi yang lain, karena parameter benar-salah dalam kaidah-kaidah ini tidak berbeda. Parameter tersebut adalah manfaat yang cukup layak untuk dijadikan timbangan baik dalam masalah etika maupun aturan perundangan. ${ }^{13}$

Abû Zahrah berupaya menelusuri akar masalah yang menyebabkan sebagian fuqahâ keberatan untuk menerima maslahat sebagai dalil hukum yang mandiri. Menurutnya-dengan meminjam konsep Mill—keberatan terhadap pandangan tersebut disebabkan adanya kekaburan terhadap apa yang dimaksud dengan maslahat. Mereka menegasikan maslahat sebagai dalil independen, karena hal itu berarti menetapkan hukum dalam agama sekeinginan diri dan dengan hawa nafsu. Misalnya, al-Ghazâlî (w. $550 \mathrm{H}$ ) berpendapat bahwa berpegang pada maslahah mujarradah yang tidak didukung teks-teks shar'î berarti menetapkan hukum sekehendak diri. Imam Ḥaramayn (w. $478 \mathrm{H}$ ), sebelum al-Ghazâlî, menegasikan penggunaan maslahat tanpa terlebih dahulu menelusuri dalil nasss dan memandang tindakan ini sama dengan menetapkan hukum kepada orang awam sesuai hawa nafsu (taḥkim lì al-awâm bî ḥasab abwâibim). Bahkan Imam al-Shâfîî juga mengritik tajam hal ini. Atas dasar itu, Abû Zahrah yakin bahwa penjelasan tentang apa yang dimaksud dengan maslahat mampu menghilangkan kekaburan yang melekat padanya. Sebagaimana para pendukung teori manfaat dalam filsafat etika di Barat juga menghadapi kritik dan sanggahan. Hal itu disebabkan kata "manfaat" yang hendak dijadikan sebagai tolok ukur tindakan moral belum dipahami secara benar oleh para pengkritiknya. Karena itu, Mill merasa perlu untuk menjelaskan arti "manfaat" secara holistik, sehingga mampu menghilangkan anomali dalam teori etika mereka

${ }_{13}$ Muhammad Abû Zahrah, Mâlik: Hayâtuh wa 'Așruh, Ârâub wa Fiqhuh (Kairo: Dâr al-Fikr al-'Arabî, t.th), 314. 
dengan cara menjelaskan hakikat teori manfaat kepada para penentangnya. ${ }^{14}$

Anehnya, kata Abû Zahrah, sejak awal kehadirannya dalam sejarah filsafat Yunani, aliran manfaat selalu mendapatkan kritik tajam. Sebab banyak filsuf terkemuka menyatakan bahwa pandangan yang memandang manfaat atau kelezatan sebagai tujuan paling utama dalam kehidupan sangat meluluhlantahkan martabat manusia dan hanya cocok untuk seekor babi yang menyerupai para pengikut Epikuros pada masa lampau. Kritik tersebut lalu dijawab Mill dengan menyatakan bahwa justru para pengritik adalah orang yang merendahkan derajat manusia, sebab dasar kritik mereka menyatakan bahwa manusia tidak memiliki potensi untuk meraih manfaat atau kenikmatan yang lebih tinggi daripada kelezatan (kepuasan) yang dirasakan seekor babi. Sesungguhnya, kenikmatan seekor babi tidak sama dengan kebahagiaan manusia, karena manusia merasa nikmat dengan potensi yang lebih tinggi daripada sekadar nafsu binatang. Hanya dengan menyadari potensi tersebut, manusia tidak melihat kebahagiaan kecuali apa yang menumbuhkan kenikmatan lebih tinggi tersebut. Abû Zahrah memberi catatan bahwa Epikuros melihat bahwa tolok ukur keutamaan adalah manfaat individual dalam bentuk tertingginya. Namun pandangan ini diubah oleh Bentham dan Mill, yang menyatakan bahwa tolok ukur tindakan moral manusia adalah menghasilkan manfaat untuk sebanyak mungkin orang dengan kualitas sebesar mungkin (al-manfaah li akbar 'adad bi akbar qadr). ${ }^{15}$

Namun aliran manfaat (utilitarianism) dikritik di Eropa setelah masuknya agama Kristen dari sisi yang berbeda dengan kritik yang ditujukan pada maslahat dalam Islam, yaitu menjadikan manfaat sebagai tolok ukur tindakan moral bertentangan dengan prinsip asketisme yang menjadi misi utama agama Kristen. Oleh karena itu, para akademisi Eropa yang membela aliran utilitarianisme mengompromikan antara asketisme dan utilitas. Namun, hal seperti ini tidak terjadi di dalam fiqh Islam untuk menjadikan maslahah sebagai dasar untuk menetapkan hukum. Sebab, menurut Abû Zahrah, kehidupan asketik (zubd) tidak termasuk ajaran Islam. Zubd dalam Islam adalah tindakan positif untuk memberikan manfaat bagi orang lain, meskipun dengan mengorbankan kepentingan individual, sebagaimana dilakukan para tokoh asketik awal Islam, semacam Abû

14 Ibid., 316-317.

${ }^{15}$ Ibid., 317. 
Bakr, 'Umar, 'Uthmân, 'Alî, para siddiqîn, dan para shubadâ. Islam tidak mengajarkan penyiksaan jasmani demi kesucian rohani, akan tetapi Islam mengajarkan penguatan rohani demi menjalankan kewajiban rohani. ${ }^{16}$

Dengan demikian, Abû Zahrah menegaskan adanya titik temu antara sebagian fuqabâ yang menjadikan maslahat sebagai metode istinbât hukum dengan para filsuf yang menjadikan manfaat sebagai tolok ukur yang dapat dipertanggungjawabkan terhadap tindakan moral. Ia meyakini bahwa penjelasan tentang maslahah mu'tabarah dan kedudukannya akan dapat menghilangkan kesalahpahaman yang melekat padanya sebagaimana dilakukan para pendukung aliran utilitarianisme modern dalam menjelaskan hakikat manfaat untuk menghilangkan kesalahpahaman para pengritiknya yang melekat pada ide tentang 'manfaat'. Menurut Abû Zahrah, hakikat maslahat yang bisa dijadikan sebagai dalil hukum agama dalam sharî‘ Islam adalah maslahat yang sesuai dengan tujuan-tujuannya (maqâsid al-sharî‘ab), yaitu memelihara lima hal yang disepakati ulama tentang kewajiban untuk memeliharanya yaitu jiwa, akal, harta, keturunan, dan kehormatan. Semua agama sepakat mewajibkan memeliharanya dan semua akal sehat manusia juga sepakat bahwa tegaknya suatu komunitas tergantung pada pemeliharaan terhadapnya. Menurutnya, lima hal ini tidak boleh dilanggar baik dalam aturan perundangan manapun baik yang didasarkan pada pandangan agama tertentu maupun didasarkan pada akal sehat manusia, seperti undang-undang Athena. Dalam kaitannya dengan tindakan-tindakan dalam upaya pemeliharaan terhadap lima hal ini, Abû Zahrah menukil pembagian ulama uṣ̂ul al-fiqh terhadapnya menjadi tiga, yaitu darûriyât, hajajyât, dan tahsinîyat. ${ }^{17}$

Adapun definisi maslahah mursalah menurut Abû Zahrah adalah maslahat-maslahat yang sesuai dengan tujuan hukum Islam yang tidak didukung oleh dalil tekstual tertentu baik yang menegasikan maupun menegaskan. Jika maslaḥah tersebut didukung oleh dalil tekstual tertentu, maka mașlạ̣ah tersebut masuk ke dalam kategori qiyâs secara umum. Akan tetapi jika maslahah tersebut didukung oleh dalil tekstual

\footnotetext{
16 Ibid., 218-219.

${ }^{17}$ Ibid., 321.
} 
tertentu yang menegasikan, maka ia batal dan menggunakan maslahah jenis ini termasuk menentang tujuan hukum Islam. ${ }^{18}$

Berdasarkan definisi Abû Zahrah di atas, dapat disimpulkan beberapa hal, yaitu:

1. Sebagian maslahah didukung oleh dalil tekstual tertentu. Maslaḥah semacam ini termasuk dalam kategori qiyâs secara umum. Atau bisa dikatakan maslahah jenis ini adalah maslahah mansûsah.

2. Sebagian maslaḥah tidak didukung oleh dalil tekstual tertentu baik yang menegasikan maupun yang menegaskan, akan tetapi maslabah ini sesuai dengan tujuan hukum Islam (maqâsid al-sharîab). Maslaḅah jenis ini disebut maslahah mursalah atau dapat juga dikatakan sebagai maslahah ghayr mansûsah.

3. Sebagian maslahah didukung oleh dalil tekstual tertentu yang menegasikan adanya maslahah. Maslahah jenis ini harus dinegasi karena bertentangan dengan tujuan hukum Islam.

4. Tujuan hukum Islam menjadi tolok ukur yang sangat menentukan diterima atau ditolaknya suatu maslahah tertentu.

\section{Identifikasi Mașlahah dan Mafsadah pada Tindakan Manusia}

Menurut Abû Zahrah, maslahat tidak bisa dilepaskan dari kerusakan (mafsadab), pun sebaliknya. Manfaat selalu terkait erat dengan kerugian, dan kerugian tidak terlepas dari manfaat. Dengan menyadur al-Shâtibî, Abû Zahrah menyatakan bahwa semua maslahat selalu diiringi takliff(pembebanan) dan tanggung jawab, seperti makan, minum, berpakaian yang tidak akan pernah dicapai kecuali dengan usaha dan kerja keras, sebagaimana kerugian duniawi bukan merupakan kerugian murni dilihat dari sisi eksistensinya. Tidak satu pun kerugian yang diyakini selalu ada di dalam adat kebiasaan yang berlaku kecuali ia diiringi oleh kelembutan, kasih sayang, dan perolehan banyak kelezatan. Sebab kehidupan dunia ini dirancang untuk menggabungkan dua hal, mașlahat dan mafsadah. Siapa pun yang berupaya ingin melepaskan diri dari salah satunya, maka ia tidak akan mampu melakukannya. Pengalaman empiris telah membuktikan hal itu. Sebab dunia adalah rumah ujian. ${ }^{19}$

Abû Zahrah juga mengulas panjang lebar pendapat Ibn Qayyim (w.751 H) yang senada dengan al-Shâtibî (w. $790 \mathrm{H}$ ) bahwa mașlaḥah,

18 Abû Zahrah, Ușûl al-Fiqh, 252.

19 Ibrâhîm b. Mûsâ Abû Ishâq al-Shâtibî, al-Muwâfaqât fi Ușull al-Sharîah, Vol. 2 (Saudi Arabia: Dâr Ibn 'Affân, 1997), 44-45. 
kebaikan, kelezatan dan kesempurnaan hanya dapat dicapai dengan jalan susah payah. Abû Zahrah mengutip kategorisasi mașlạ̣ah dan mafsadah yang dilakukan oleh Ibn Qayyim. Ia membagi tindakan hukum manusia dalam hubungannya dengan maslahah dan mafsadah menjadi lima kategori, yaitu: 1). tindakan hukum bersifat maslaḥah murni, 2). tindakan hukum yang dominan maslahatnya, 3). tindakan hukum yang bersifat mafsadah murni, 4). tindakan hukum yang dominan mafsadah-nya, dan 5), tindakan hukum yang maslahah dan mafsadah sama. ${ }^{20}$

Pembagian ini menurut Abû Zahrah dilakukan secara rasional tanpa mempertimbangkan kenyataan yang ada di lapangan. Dalam realitanya, para akademisi berbeda pendapat terkait dengan tiga kategori dan sepakat mengenai dua kategori. Mereka sepakat mengenai kategori kedua dan kategori keempat. Adapun mengenai tiga kategori lainnya, para akademisi mereka berbeda pendapat. ${ }^{21}$

Abû Zahrah menjelaskan bahwa menurut sebagian ulama, tindakan hukum bersifat manfaat murni dan tindakan hukum bersifat mafsadah murni tidak ada dalam kenyataan empriris. Menurut Ibn Qayyim, maslaḥah adalah kenikmatan dan kelezatan dan apapun yang menjadi sarana padanya dan mafsadah adalah siksaan dan rasa sakit dan sarana yang mengantarkan padanya. Namun menurut sebagian lainnya, manfaat murni dan kerugian murni memang ada dalam kenyataan. Mereka memberikan alasan bahwa para nabi pilihan dan para malaikat suci adalah contoh manfaat murni dan iblis dan pengikutnya adalah kerugian murni. Jika memang ada sebagian orang yang baik murni berarti tindakan manusia pun ada yang manfaat murni dan kerugian murni. ${ }^{22}$

Untuk mengompromikan dua pendapat yang saling berseberangan tersebut, Abû Zahrah mengutip pendapat Ibn Qayyim yang telah disimpulkannya sebagai berikut: Pertama, sebagian maslahat memang ada yang bersifat murni, akan tetapi ada kesulitan yang harus dijalani dengan sabar dalam proses mendapatkan kemaslahatan tersebut. Dengan demikian, maslahah bersifat murni, akan tetapi jalan untuk mencapainya penuh pengorbanan. Kedua, besarnya kesulitan tergantung besarnya mașlạ̣ah murni. Semakin murni mașlạ̣ah itu,

20 Ibn Qayyim al-Jawzîyah, Miftâh Dâr al-Sa'âdah wa Manshûr Wilâyat al-Tlm wa alIrâdah (Beirut: Dâr al-Kutub al-'Ilmîyah, 1998), 331.

${ }^{21}$ Abû Zahrah, Mâlik, 338.

22 Ibn Qayyim, Miftâh Dâr al-Sa âdah, 331. 
maka kesulitan, energi, dan kesabaran akan semakin besar. Ketiga, semakin mulia jiwa dan semakin luhur cita-cita seseorang, maka raganya akan semakin payah dan semakin sedikit istirahat. Kemanfaatan individual bagi pelakunya bersifat maknawi (rohani), sedangkan manfaat materinya bersifat bisa ditunda, tidak sekarang. ${ }^{23}$

Berdasar pembacaan terhadap kompromi yang dilakukan Ibn Qayyim di atas, Abû Zahrah menyimpulkan bahwa pandangan ini sejalan dengan pandangan para ahli etika yang mendukung teori utilitarianisme di Barat. Mereka menyatakan bahwa manfaat individual kadang-kadang bersifat maknawi (spiritual) ketika manusia berjiwa mulia dan bercita-cita luhur. ${ }^{24}$

Muḥammad Sacîd Ramaḍân al-Bûṭ̂i (w. 2013 M) menegaskan bahwa kemaslahatan manusia tidak boleh bertentangan dengan mafsadah yang setara atau yang lebih dominan sehingga kehilangan nilai dan manfaatnya. Seperti orang yang menelan obat untuk mengobati rasa sakit yang ada di perutnya, namun ternyata menyebabkan sakit kepala. Namun ketika kemaslahatan dibarengi mafsadah yang lebih kecil darar-nya, maka sesungguhnya tidak ada pertentangan dalam hal ini, karena akal sehat akan menuntut untuk menanggung darar yang kecil demi memperoleh kemaslahatan yang dapat menolak darar yang besar. ${ }^{25}$

Kesulitan dilihat dari sisi rasa sakit yang ditimbulkan termasuk mafsadah, akan tetapi ia berubah menjadi kemaslahatan jika digunakan sebagai sarana untuk mewujudkan kemaslahatan. Seperti seseorang yang makanannya tertahan di tenggorokan karena tidak ada air sama sekali di sekitarnya kecuali segelas minuman keras yang jika tidak diminum, maka dia akan mati. Kemaslahatan dalam hal ini bertentangan dengan mafsadah yang setara dengannya atau lebih dominan. Ia diperkenankan untuk mengonsumsi minuman keras demi memelihara kepentingan dasarnya, yaitu menjaga kelestarian jiwa. Adapun kesulitan yang lebih rendah dari itu yaitu kesulitan yang terjadi dalam pekerjaan dan tugas hidup keseharian, maka bukan termasuk kesulitan yang hendak dihilangkan oleh Allah ( raf $^{\prime}$ al-ḥaraj). Al-Bûtî menjelaskan bahwa perintah-perintah agama di-sharî‘ $a h-k a n$

23 Abû Zahrah, Mâlike, 324.

24 Ibid., 325. Lihat juga John Stuart Mill, Utilitarianism (New York: McGraw Hill, 2001), 107.

25 Muhammad Saî̀d Ramaḍân al-Bûțî, Dawâbit al-Mașlahah fî al-Sharîab al-Islâmîyah (Damaskus: Dâr al-Fikr, 2005), 112-113. 
demi merealisir kemaslahatan manusia. Kesulitan yang melekat pada pelaksanaan setiap perintah agama adalah lebih kecil dibandingkan kemaslahatan yang hendak diperoleh. ${ }^{26}$

Persoalan berikutnya yang menjadi perdebatan di antara para ulama dalam kaitannya dengan hubungan maslahah dan mafsadah adalah kategori kelima yang menyatakan adanya tindakan hukum yang maslahah dan mafsadah-nya sama. Sebagian ulama, misalnya Najm alDîn al-Tûfî, menyatakan bahwa kategori ini ada dalam kenyataan. Namun sebagian lain, yaitu Ibn Qayyim menyatakan sebaliknya. Abû Zahrah sepakat dengan Ibn Qayyim bahwa kategori semacam ini meskipun secara rasional dimungkinkan, namun tidak ada bentuk riilnya. Mengandaikan tindakan yang manfaat dan kerugiannya sama adalah tidak mungkin, sebab yang ada dalam kenyataan hanyalah tindakan hukum yang dominan maslaḥah atau dominan mafsadah-nya, sehingga kebolehan maupun larangan tergantung pada hal yang dominan. Terkadang ada suatu tindakan hukum yang dominan mafsadah-nya pada suatu waktu tertentu dan di waktu lainnya kemaslahatannya lebih dominan, sehingga ketetapan hukumnya ditentukan berdasarkan pada tindakan manakah yang dominan pada suatu waktu tertentu. Dengan demikian, hukum dapat berbeda bergantung pada perbedaan situasi dan keadaan. ${ }^{27}$ Hal ini didukung pendapat al-Râzî (w. $606 \mathrm{H}$ ) yang membagi tindakan manusia dalam kaitannya dengan mașlahah dan mafsadah menjadi enam kategori, antara lain: 1). Maslahah murni. Kemaslahatan tipe ini wajib diupayakan, 2). Mașlahah lebih dominan. Tipe kemaslahatan ini wajib direalisir, 3). Mașlahah dan mafsadah seimbang. Kategori ini tidak ada ('abath). Maslahah ini tidak boleh direalisasikan, 4). Maslahah dan mafsadab tidak ada di dalamnya. Kategori ini tidak ada ('abatb) Tindakan semacam ini tidak boleh direaliasikan, 5). Mafsadah murni. Tindakan semacam ini tidak boleh direalisir, dan 6). Mafsadab lebih dominan. Tindakan semcam ini tidak boleh direalisasikan. ${ }^{28}$

Menurut Abû Zahrah, pendapat Ibn Qayyim dan al-Râzî (w. 606 $\mathrm{H}$ ) ini rasional dan sesuai dengan yang ada pada kenyataan empiris. Namun al-Tûfî justru berpendapat sebaliknya dengan pengandaian adanya sesuatu yang sama antara manfaat dan kerugiannya dan antara

${ }^{26}$ Ibid., 112-113.

27 Abû Zahrah, Mâlik, 325-326.

${ }^{28}$ Fakhr al-Dîn al-Râzî, al-Mahṣ̂ul fî Tlm Uș̂́l al-Fiqh, Vol. 6 (Beirut: Muassasat alRisâlah, 1998), 165. 
maslahah dan mafsadah dalam realitas empiris. Jika keduanya sama, maka jalan keluarnya adalah melalui proses pemilihan atau pengundian (al-ikhtiyâr aw al-qur'ab). ${ }^{29}$ Abû Zahrah mengritik al-Ṭ̂ufi dengan argumen-argumen yang telah dikemukakan Ibn Qayyim. Telaah empiris menunjukkan tidak ada sesuatu pun yang sama kadar manfaat dan bahaya dalam lintas keadaan dan untuk semua orang. Yang ada adalah sesuatu yang berbeda-beda maslahah dan mafsadah antar-manusia dan perbedaan kondisi seorang individu serta perbedaan adat kebiasaan umat manusia. Ibarat obat hanya bermanfaat di kala sakit dan membahayakan di kala sehat. Perbedaan akibat tergantung pada keadaan sakit dan sehat, meskipun karakteristik sebab-sebab tersebut tidak berbeda dan tidak berubah. ${ }^{30}$

Abû Zahrah menuntut al-Ṭûfî untuk menjelaskan secara ilmiah dengan mengemukakan satu contoh faktual penetapan hukum Islam tentang kemungkinan adanya suatu hal yang manfaat dan darar-nya sama. Sebab persoalan ini merupakan arena perbedaan pendapat di kalangan fuqabâ mengenai kemungkinan adanya. Ia juga mempertanyakan, kalau memang terdapat kesamaan antara manfaat dan kerugiannya di realitas empiris, maka pertanyaan yang muncul adalah mengapa al-Tûfî mengajukan cara penentuan hukumnya justru menggunakan pengundian. Jika hasil pengundian mengandung kerugian, berarti kita wajib melakukan kerugian, karena itulah yang ditetapkan hasil pengundian. Jika pengundian menghasilkan tuntutan untuk meninggalkan, berarti kita harus meninggalkannya, meskipun terdapat manfaatnya, yang mana kita justru dituntut untuk melakukannya. ${ }^{31}$

Kebenaran menuntut untuk mencari jalan keluar selain berpegang pada pengundian, yaitu memandang seseorang dari sisi kebutuhannya terhadap sesuatu. Jika ia berada pada suatu kebutuhan (ḅajah) yang menuntutnya untuk menghasilkan manfaat, sedangkan darar yang mengiringi kebutuhan tersebut lebih ringan, maka manfaat tersebut harus diupayakan karena maslahah-nya lebih dominan. Jika ia berada pada suatu kebutuhan mendesak, maka sisi darar harus dipertimbangkan, karena menolak kerugian didahulukan daripada menghasilkan maslaḥah ini merupakan cara berpikir yang tepat.

${ }^{29}$ Najm al-Dîn al-Ṭufî, Risâlah fì Ríâyat al-Mașlạ̣ah (Beirut: Dâr al-Maṣdarîyah alLubnânîyah, 1993), 46.

30 Abû Zahrah, Mâlike, 327.

31 Ibid., 327. 
Seseorang yang berada pada kondisi mendesak diperkenankan memakan daging babi, meski ada darar di dalamnya dan diperbolehkan makan bangkai meski tidak disukai manusia saat dalam kondisi biasa. Cara pandang seperti ini akan mengantarkan pada penentuan prioritas satu sisi atas sisi yang lain, meski hanya didasarkan pada pertimbangan individual. Cara penentuan prioritas semacam ini cukup memadai untuk menetapkan hukum Islam dan menempatkannya pada landasan yang kokoh, bukan pada landasan pengundian.

Atas dasar itu, berbagai tindakan hukum manusia di dunia ini terkadang lebih dominan manfaatnya, atau lebih dominan kerugiannya. Jarang sekali tindakan manusia yang bersifat manfaat murni atau darar murni. Tidak mungkin ada perbuatan yang sama kualitas manfaat dan kerugiannya dari semua sudut, dalam semua keadaan dan bagi semua orang. Menurut Abû Zahrah, penetapan hukum harus dilandaskan pada asas yang kokoh, dan tidak boleh didasarkan pada asas pengundian. Sesungguhnya sisi maslabah dituntut untuk dilakukan, sedangkan sisi kerugian adalah dilarang. Jika sharî‘ $a h$ menuntut melakukan sesuatu, maka yang dituntut adalah maslaḥah, sedangkan kerugian tidak dituntut di dalamnya kecuali secara ikutan/tidak langsung, tidak secara sengaja/langsung (lâ bi al-qașd).

Kerusakan tidak mungkin menjadi maksud dan keinginan shara, meski sebagai maksud yang ikutan (taba'an), sebagaimana tidak mungkin sama sekali bahaya dituntut untuk dilakukan. Demikian pula, ketika Shâri' melarang sesuatu yang didalamnya ada maslahat yang tidak dominan (ghayr râjị̧ah), maka Shâr t tidak sedang melarang melakukan maslahah baik secara sengaja maupun secara ikutan. Akan tetapi Dia melarang kerugian karena kerugian itu sendiri. Dengan demikian, larangan terhadapnya bersamaan dengan larangan terhadap sebagian maslahah. ${ }^{32}$

Pandangan Abû Zahrah ini sesuai dengan pandangan 'Izz al-Dîn b. 'Abd al-Salâm (w. $660 \mathrm{H}$ ) yang menyatakan bahwa yang dipandang sebagai maslahah bukan hanya maslahah itu sendiri, akan tetapi juga semua sebab yang mengantar pada maslaḥah juga. ${ }^{33}$ Abû Zahrah menganalogikan Tuhan dalam hal ini dengan dokter yang merekomendasikan obat yang sangat pahit kepada pasien yang ditanganinya untuk diminum. Obat itu diberikan bukan karena rasa

\footnotetext{
32 Ibid., 328.

33 'Izz al-Dîn b. 'Abd al-Salâm, Qawâid A Ạkâm fi Islạh al-Anâm (Damaskus: Dâr alQalam, t.th), 17.
} 
pahitnya yang kuat, yang merupakan sisi kerusakan, akan tetapi direkomendasikan karena di dalamnya terdapat obat. Sebagaimana dokter juga melarang pasiennya dari mengonsumsi sebagian makananmakanan yang dihalalkan (tayyibât) pada saat ia sakit karena dikhawatirkan akan membuat sakitnya semakin parah. Hal itu dilakukan bukan karena ada sisi manfaat pada makanan tersebut, akan tetapi karena ada sisi kerugian yang diakibatkannya, yaitu ketidakmampuan alat pencernaan untuk mencernanya dengan baik yang menyebabkan penambahan beban pada tubuh dan otot si pasien. Melalui analogi tersebut, Abû Zahrah menyimpulkan bahwa Tuhan hanya memberikan perkenan terhadap sesuatu yang merupakan maslabah dan melarang sesuatu yang merupakan mafsadah. Ia menyatakan bahwa menemukan dan mengetahui berbagai sisi maslahah dalam semua persoalan duniawi adalah berada dalam jangkauan kemampuan akal manusia. Ia akan menemukan maslahah tersebut berlandaskan pada perintah Tuhan, walaupun tidak ada dalil tekstual yang jelas dan khusus. Sebab perintah-perintah yang bersifat deduktif dan hukum-hukum yang bersifat induktif menununjukkan bahwa sharî́ah Islam baik secara global (kulli) maupun parsial (juz'i) ditujukan untuk memroduksi maslahah dan menghindari mafsadah. ${ }^{34}$

Selanjutnya, Abû Zahrah menjelaskan cara mengetahui maslahah dalam kaitanya dengan persoalan-persoalan yang bersifat ibadah murni dan ibadah sosial. Menurutnya, dalam hal-hal yang berkaitan dengan hubungan manusia dengan Tuhannya, maka cara mengetahui berbagai sisi maslahah-nya tidak mudah. Walaupun demikian, manusia dapat mengetahui dan menemukan hikmah-hikmahnya yang berkesesuaian dengan maslaḥah, meski dalam tataran global. Oleh karena itu, manusia diperkenankan menetapkan suatu ibadah tertentu tanpa didukung oleh dalil tekstual tertentu. Sebab jika ia melakukan hal itu, maka berarti ia telah melakukan bid'ah di dalam agama. Menurut fuqabâ, tegas Abû Zahrah, ketika beberapa maslahah kontraproduktif, yaitu ketika maslahah komunitas tertentu merupakan darar bagi komunitas lainnya atau ketika maslaḥah pada suatu aspek kehidupan manusia merupakan darar pada aspek kehidupan lainnya, maka fuqahâ dalam kedua hal ini menangani dengan cara yang serupa dengan para pendukung teori utilitarianisme. ${ }^{35}$

\footnotetext{
34 Abû Zahrah, Mâlik, 329.

35 Ibid., 340.
} 
Hal lain yang perlu didudukkan pada posisi sebenarnya, menurut Abû Zahrah, adalah ketika terjadi benturan internal di antara beberapa maslahah dan di antara beberapa mafsadah. Dalam arti ketika memilih suatu maslahah berarti mengabaikan maslahah lainnya. Atau dalam menegasikan sebagian mafsadah pada suatu komunitas dikhawatirkan menimbulkan darar pada komunitas lainnya. Menurut fuqahâ yang secara intensif mendalami kajian maslaḥah, dalam hal terjadi benturan sebagaimana tersebut di atas, yang dipilih adalah yang paling banyak menghasilkan maslahah dari sisi kuantitas dan seberapa banyak kebutuhan manusia terhadapnya, dan yang paling banyak menghindarkan mafsadah dari sisi kuantitas dan kuatnya rasa sakit yang diderita. Abû Zahrah menguatkan pendapatnya dengan mendasarkan pada pendapat al-Shâttibî (w. 790 H), Ibn Qayyim (w. 751 H) dan alTûfî (w. $716 \mathrm{H}){ }^{36}$

Berdasarkan pendapat ketiga tokoh ini, Abû Zahrah menyimpulkan bahwa maslaḥah atau manfaat yang dituntut dihasilkan oleh Tuhan adalah manfaat potensial untuk kuantitas paling banyak orang dengan kualitas potensial yang paling kuat dan bahwa kerugian yang dituntut untuk dihindarkan adalah kerugian yang paling kuat menimpa kuantitas paling banyak orang. Menurut Abû Zahrah, manfaat dan kerugian dalam hal ini bersifat relatif dan cara pandang seperti ini cocok dengan pandangan para ahli etika dari aliran utilitarianisme dalam bidang hukum dan moral. ${ }^{37}$

Abû Zahrah mengutip perkataan Jeremy Bentham sebagai berikut:

Sesungguhnya manfaat itu beragam. Kadang-kadang dua manfaat saling berbenturan pada suatu waktu tertentu. Dalam hal ini yang dinamakan keutamaan adalah meninggalkan manfaat yang kecil dalam upaya meraih manfaat yang besar. Atau meninggalkan manfaat yang bersifat temporer dalam rangka menghasilkan manfaat yang abadi. Atau meninggalkan manfaat yang meragukan dalam rangka mencapai manfaat yang meyakinkan. Dengan cara seperti ini, pemahaman tentang arti 'manfaat' bisa dikuak secara gamblang dan apa pun upaya memahaminya melalui cara yang tidak seperti ini dikhawatirkan akan mengantar kepada kekeliruan dalam memahaminya. ${ }^{38}$

\footnotetext{
${ }^{36}$ Ibid., 331.

37 Ibid., 332.

38 Jeremy Bentham, An Introduction to The Principles of Morals and Legislation (Kitchener: Batoche Books, 2000),15.
} 
Dalam kaitan ini, fuqahâ menegaskan bahwa terealisasinya lima mașlahah tersebut bersifat relatif (nisbî-idâfî). Tidak ada suatu tindakan tertentu secara khusus bisa menimbulkan maslahah yang kuat. Berbagai tindakan menjadi objek tarik menarik berbagai bentuk maslahah kecuali prinsip-prinsip umum moral. Sebab realisasi maslahab lima sangat kuat di dalamnya. Suatu tindakan kadang-kadang menimbulkan kerugian terhadap suatu komunitas, namun di sisi lain membawa manfaat bagi komunitas lainnya, atau menimbulkan kerugian di suatu negeri, namun membawa manfaat bagi negeri lainnya. Suatu tindakan terkadang membawa kerugian pada suatu zaman, namun mengandung manfaat pada zaman yang lain. Demikian seterusnya. ${ }^{39}$

Menurut Abû Zahrah, pada situasi tersebut, suatu tindakan dinilai dari sisi menimbulkan kerugian dan membawa manfaat. Dan dari sisi hukum shariah, suatu tindakan dinilai dari kadar manfaat terbesarnya (akbar qadr min al-naf). Di samping itu, tindakan tersebut juga dilihat dari sisi jangka waktu kemanfaatan yang paling lama. Manfaat dinilai tidak terbatas pada yang bersifat fisik (mâdîyah) belaka, akan tetapi juga manfaat yang bersifat non-fisik (ma'nawijyah). Sebagai contoh manfaat yang berhubungan dengan pemeliharaan agama dan akal secara lahir merupakan manfaat ma'nawiyah, meskipun hasil akhirnya merupakan manfaat fisik juga. Sebab kelurusan akal dan ketenangan jiwa menyebabkan terjadinya pembagian materi secara adil dengan timbangan yang lurus dan meningkatkan produktivitas yang membuahkan hasil yang memberikan manfaat kepada umat manusia. ${ }^{40}$

Dengan pendapat ini, Abû Zahrah hendak menunjukkan bahwa dirinya mengutip pendapat Bentham dan Mill sebagai kesatuan untuk mengukur maslahah dan mafsadah. Dari Bentham, ia mengambil kalkulasi kepuasan bahwa tindakan yang seharusnya diambil adalah tindakan yang dinilai memiliki kadar manfaat terbesar untuk sebanyak mungkin orang dengan jangka waktu paling lama. Ia lebih menekankan tingkatan dengan durasi kepuasan dalam jangka waktu lama, karena hal itu yang paling penting di antara kriteria kalkulasi maslahah dan mafsadah. Abû Zahrah sering kali menggunakan tiga parameter di atas, meski sebenarnya ada tujuh parameter untuk mengalkulasi kepuasan tindakan menurut Bentham. Sedangkan dari

${ }^{39}$ Muḥammad Abû Zahrah, al-Mujtama' al-Insânî fî Ẓill al-Islâm (Kairo: Dâr al-Fikr al'Arabî, t.th.), 52.

${ }^{40}$ Ibid., 53. 
Mill, ia mengambil perbedaannya antara maslahahah fisik dan mașlạ̣ah non-fisik dan maslahah non-fisik harus lebih didahulukan.

\section{Aplikasi Utilitarianisme pada Bidang Pidana Islam}

Menurut Abû Zahrah, pranata sosial dalam Islam baik yang berhubungan dengan transaksi harta maupun hukum pidana didasarkan pada suatu prinsip moral yang sama, yaitu memelihara maslaḥah sebesar mungkin bagi manusia, baik berupa manfaat fisik atau non-fisik, di masa kini atau di masa mendatang. Selama manfaat di masa datang dipertimbangkan, maka upaya ke arah kenikmatan akhirat akan mempermudah manusia dalam menghadapi kesulitankesulitan hidup di dunia. Orang-orang semacam ini, menurut Abû Zahrah, akan mendapatkan dua kenikmatan, yaitu: pertama, kenikmatan melakukan kebaikan untuk orang banyak, dan kedua, kenikmatan yang akan didapatkan di hari akhir. Dengan demikian, mereka mendapatkan manfaat yang bersifat non-fisik (ma'nawiyah) dan fisik (mâdîyah). ${ }^{41}$

Dalam rangka mengungkap lebih jauh tentang arti tindak pidana, Abû Zahrah terlebih dahulu menjelaskan apa yang dimaksud buruk (sharr) dan baik (khayr) dalam ranah etika dari sudut pandang para pakar etika dari aliran utilitarianisme. Menurut mereka, suatu tindakan dikatakan sebagai buruk manakala memberikan efek merugikan (darar) bagi masyarakat dan dikatakan baik jika tidak membahayakan bagi masyarakat. Hal ini disebabkan aliran ini memandang standar nilai baiknya suatu tindakan ditentukan oleh kualitas manfaat paling besar yang dihasilkan oleh tindakan tersebut bagi kuantitas paling banyak orang yang dimungkinkan untuk mendapatkannya. Menurut mereka, manfaat tidak selalu bersifat materi. Namun manfaat bisa bersifat rohani dan juga materi. Manfaat juga tidak terbatas pada manfaat jangka pendek, akan tetapi juga termasuk manfaat jangka panjang. ${ }^{42}$

Abû Zahrah menambahkan bahwa menolak hal-hal yang merugikan juga termasuk manfaat, seraya menyatakan bahwa standar nilai utilitarianisme merupakan standar nilai paling jelas (awdaḥ almaqâyis), paling mendekati aturan-aturan perundang-undangan yang adil dan solidaritas sosial, yang memandang manusia sebagai makhluk sosial yang hidup dalam suatu lingkungan yang mana ia bisa mendapatkan manfaat darinya dan ia bisa memberikan manfaat di

\footnotetext{
${ }^{41}$ Ibid., 82.

42 Muhammad Abû Zahrah, al-Jarimah wa al-Uqûbah fî̀ al-Fiqh al-Islâmî: Jarîmah (Kairo: Dâr al-Fikr al-'Arabî, t.th.), 22.
} 
dalamnya. Menurut Abû Zahrah, ketentuan moral meliputi tindakan dan maksud yang mendasarinya. Seseorang tidak bisa dikatakan baik kecuali jika dia bermaksud melakukan tindakan baik. Hal ini sangat sesuai dengan standar moral dan etika agama Islam. Demikian pula, seseorang baru dikatakan buruk manakala ia beritikad buruk dan melakukan tindakan buruk. ${ }^{43}$

Atas dasar itu, dengan menukil pendapat Bentham, Abû Zahrah memandang bahwa undang-undang moral dan hukum memiliki kesamaan dalam menilai tindak pidana secara umum. Perbedaannya terletak pada pemaknaan tindak pidana secara khusus. Secara moral, tindakan buruk lebih umum daripada suatu tindakan yang dikenai sanksi hukum ('uquibah), karena ia mencakup tindakan buruk yang dikenakan sanksi berdasarkan hukum perundang-undangan dan tindakan buruk yang berada di luar jangkauan lembaga peradilan. Hal itu disebabkan ada banyak perkara yang tidak berlaku padanya proses pembuktian, yang seandainya hakim tetap bersikeras untuk memroses pembuktiannya, niscaya akan mendorongnya untuk membelah dada manusia. Tindakan seperti itu pada dasarnya tidak akan mengantar kepada kebaikan. Bahkan sebaliknya keburukan yang ditimbulkan lebih banyak daripada kebaikan yang dihasilkan sebagai akibat penetapan sanksi pada tindakan tersebut. Sebab undang-undang moral menuntut agar tidak ada pengungkapan terhadap rahasia manusia dan memasuki hati mereka. ${ }^{44}$

Abû Zahrah menegaskan bahwa yang menjadi dasar penetapan suatu tindakan dipandang sebagai tindak pidana (jarimah) adalah karena tindakan tersebut menyalahi perintah agama (mukbâlafah awâmir al-dîn). ${ }^{45}$ Menurutnya, penetapan sanksi hukum dalam sharî‘ah Islam harus dikembalikan pada upaya menjaga lima masalib̧ (jamak dari maslaḥah), yaitu agama, jiwa, akal, keturunan, dan harta. Suatu tindakan dipandang sebagai tindak pidana manakala bertentangan lima masalith di atas yang pada dasarnya merupakan aksioma akal manusia dan kebutuhan dasar semua umat manusia dari berbagai agama. Lima hal tersebut mirip dengan prinsip moral yang diakui dan dijunjung tinggi secara universal oleh seluruh umat manusia seperti kejujuran dan keadilan yang diakui oleh semua akal manusia sebagai tindakan yang bernilai utama dan menentangnya berarti tindakan yang bernilai

43 Ibid., 22.

${ }^{44}$ Ibid., 23.

45 Ibid., 25. 
rendah. Kedua sifat ini pada dasarnya bisa dikembalikan pada pemeliharaan terhadap lima hal di atas. ${ }^{46}$

Abû Zahrah menandaskan bahwa menjaga lima hal di atas, jika dilihat dari sisi kullyyah, merupakan suatu perintah yang pasti, karena ada banyak dalil tekstual yang secara holistik menjadi penopangnya. Namun, bila dilihat dari sudut pandang parsial ada kemungkinan terjadi pertentangan. Kadang-kadang apa yang merupakan maslaḥah meyakinkan bagi sebagian orang justru merupakan kerugian yang meyakinkan bagi sebagian lainnya, bahkan kadang-kadang merupakan kerugian bagi diri orang itu sendiri. Dengan demikian, seseorang yang berjalan di atas dua kaki merupakan maslạ̣ah yang meyakinkan baginya. Namun ketika salah satu kakinya terkena penyakit kanker, maka maslaḥah semacam ini berbalik menjadi kerugian baginya. Demi maslahah seluruh bagian tubuhnya, maka salah satu kaki tersebut harus dihilangkan (amputasi). Perumpamaan sebuah kaki atau lengan di dalam tubuh manusia bagaikan seseorang yang berada di dalam komunitasnya. Maslahah meyakinkan bagi suatu tubuh manusia terjadi ketika semua anggota tubuhnya berada dalam keadaan sehat dan tetap eksis. Namun jika salah satu anggota tubuh rusak dan jika keselamatan seluruh anggota tubuh lainnya tergantung pada hilangnya satu anggota tubuh tersebut, maka anggota tubuh tersebut wajib diamputasi. ${ }^{47}$

Dengan demikian, terkadang terjadi pertentangan antara beberapa maslaḥah dan beberapa kerugian. Satu tindakan kadang-kadang di suatu waktu membawa manfaat dan di waktu lainnya membawa kerugian. Menurut Abû Zahrah, ketika terjadi pertentangan antara manfaat dan kerugian, maka tindakan yang menghasilkan manfaat paling banyak harus didahulukan. Yang layak dipertimbangkan adalah tindakan yang membawa maslahah untuk sebanyak mungkin orang dengan sebesar mungkin manfaat yang didapatkan dari tindakan tersebut. Tindakan yang menimbulkan banyak kerugian dikalahkan oleh tindakan yang membawa sedikit kerugian. Tindakan yang menolak kerugian lebih didahulukan atas tindakan yang memproduk maslahat. Sebab tindakan menolak kerugian pada prinsipnya merupakan maslahah yang membawa kepada keselamatan. ${ }^{48}$

\footnotetext{
46 Ibid., 31.

47 Ibid.

${ }^{48}$ Ibid.
} 
Ada beberapa kaidah fiqh terkait dengan maslaḥah dan kerugian sesuai dengan pemikiran hukum Abû Zahrah di atas. Sebagian di antaranya adalah:

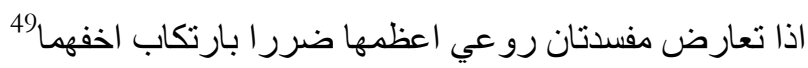

Ketika terjadi pertentangan antara dua kerugian, maka harus dihindarkan yang paling besar kerugiannya dengan melakukan yang paling ringan dari dua kerugian tersebut.

درء المفاسد اولى من جلب المصالج فاذا تعارض مفسدة ومصلحة قدم دفع المفسدة Menolak kerugian itu lebih utama dibandingkan menarik kemaslahatan, sehingga ketika ada pertentangan antara kerugian dan maslahat, maka menolak kerugian lebih didahulukan.

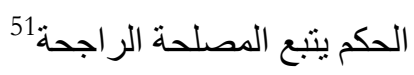

Hukum itu mengikuti maslahat yang kuat.

Atas dasar itu, Abû Zahrah menyimpulkan bahwa mașlạ̣ah suatu komunitas bersifat relatif atau situasional (idâfìah), bukan merupakan kenyataan yang bersifat substantif, ketika dilihat dari sudut pandang pada satu per satu unsur-unsurnya. Namun jika dilihat dari keseluruhan unsur-unsurnya, maka ia bersifat substantif yang pasti. ${ }^{52}$

Berdasarkan pemikiran di atas, Abû Zahrah menegaskan bahwa menjadikan manfaat yang sesungguhnya sebagai asas dalam penetapan sanksi hukum ('uqûbât) merupakan ketetapan yang tepat (al-ḥukm almustaqîm), disertai pertimbangan penetapan sanksi hukum atas suatu tindakan bagi orang yang memang berhak mendapatkannya, dalam arti yang dipandang sebagai tindak pidana (jarimab) adalah semua tindakan yang merupakan pelanggaran (itidâa) terhadap lima maslahat yang telah ditetapkan. Orang yang melakukan pelanggaran akan mendapatkan sanksi hukum sebatas beban tanggungjawab yang bisa diembannya dari tindakan yang telah dilakukannya sesuai syarat-syarat sanksi hukum yang ada dalam ketentuan shari`ah Islam. Dengan cara seperti ini, undang-undang ditetapkan demi memelihara beberapa almaslahah al-mu'tabarah yang ada di masyarakat, tanpa memberikan pengaruh sedikit pun pada keinginan pribadi dalam menentukan sanksi hukum. Penentuan sanksi hukum harus didasarkan pada paling

49 Jalâl al-Dîn al-Suyûtî, al-Ashbâh wa al-Nazâir fî al-Furú (Surabaya: al-Hidâyah, t.th.), 62 .

${ }^{50}$ Ibid., 62 .

${ }^{51}$ Ibid., 62.

52 Abû Zahrah, al-Jarimah, 34. 
tidak pada tiga hal, antara lain: 1) seberapa besar pelanggaran itu merugikan masyarakat, 2) seberapa banyak sanksi itu memberikan manfaat bagi korban, dan 3) seberapa berat beban yang bisa ditanggung oleh pelakunya. Menurut Abû Zahrah, ini merupakan asas yang tepat, sebab semua undang-undang pidana baik yang didasarkan pada wahyu maupun hasil pemikiran manusia pasti memiliki maksud yang sama yaitu mengatur kemaslahatan manusia dan melindungi mereka dari kerusakan (fasâd). ${ }^{53}$

Sejumlah pakar hukum pidana menegaskan bahwa menjadikan manfaat sebagai asas dalam penetapan hukum pidana hanya bukan merupakan tahap akhir dan tahap paling sempurna dalam pemikiran tentang penetapan sanksi hukum. Sebab ada tahap lain yang lebih tinggi darinya yaitu menjadikan keadilan sebagai dasar dalam penetapan sanksi hukum tanpa memandang pada manfaat jangka pendek maupun manfaat jangka panjang, sesuai dengan pandangan Immanuel Kant dalam bidang etika. Menurut Kant, asas utama perilaku baik manusia adalah kewajiban. ${ }^{54}$ Kewajiban adalah keadilan itu sendiri, yaitu mengasumsikan bahwa apapun yang ditetapkan undang-undang adalah berlaku atas seluruh manusia. Jika suatu perbuatan menghasilkan kebaikan dan perbaikan pada manusia dan masyarakat, maka perbuatan itu dikatakan baik. Jika perbuatan itu menghasilkan kerusakan dan kekacauan, maka perbuatan itu dikatakan buruk. Asas undang-undang adalah keadilan. ${ }^{55}$

Menanggapi hal itu, Abû Zahrah menegaskan bahwa memisahkan sanksi hukum dari arti kemanfaatan bagi masyarakat berarti memisahkan antara sebab dari akibatnya. Sebab bangunan masyarakat

\footnotetext{
53 Ibid., 34.

54 Menurut Kant perbuatan adalah baik jika hanya dilakukan karena wajib dilakukan. Seseorang baru dikatakan memasuki taraf bermoral tatkala ia melakukan suatu perbuatan semata-mata "karena hormat kepada hukum moral". Yang dimaksud hukum moral adalah kewajiban. Kant merumuskan Hukum moral sebagai suatu perintah pasti. Dengan ini yang dimaksudkannya adalah bahwa hukum moral itu atau bahwa ia berlaku untuk semua situasi. Lagi pula, ia berupa perintah yang berarti memiliki kekuatan dan kewenangan mutlak. Kant merumuskan 'perintah pasti' itu dengan ungkapannya: "Bertindaklah dengan cara sedemikian rupa sehingga kamu selalu menghormati peri-kemanusiaan, entah kepada dirimu sendiri maupun kepada orang lain, bukan hanya sekali-kali, melainkan selalu dan selamanya". Menurut Kant, hukum moral sama universalnya dengan hukum kausalitas. Itu pun tidak dapat dibuktikan dengan akal, namun tetap mutlak dan tidak dapat diubah. Jostein Gaarder, Shopie's World, terj. Rahmani Astuti (Bandung: Mizan, 2012), 517-518.

55 Abû Zahrah, al-Jarimah, 34.
} 
didirikan di atas jalinan beberapa maslahah dan berkelindannya beberapa manfaat. Berdasar pergaulan manusia semacam ini, kadangkadang sebagian pelaku bekerjasama melakukan perbuatan zalim kepada sebagian lainnya. Oleh karena itu, dalam upaya melindungi maslahah-maslahah ini undang-undang harus memberikan perlindungan kepada maslaḥah-maslahah yang diakui sharî‘ah, melarang kecurangan dan tindak kesewanang-wenangan. Sanksi hukum dapat melakukan fungsi perlindungan semacam ini jika sanksi hukum tersebut tidak memiliki unsur kesewenang-wenangan di dalamnya atau jika hukum itu adil. Dengan demikian, pemisahan keadilan dari makna manfaat berarti memisahkan sebab dari akibatnya. Sanksi hukum harus mempertimbangkan norma keadilan dan kesetaraan antara tindak pidana dan sanksi hukumnya dan kadar risiko yang mampu ditanggung pelaku tindak pidana. ${ }^{56}$

Keadilan dalam arti ini memiliki arti relatif. Atas dasar itu, Abû Zahrah menyimpulkan bahwa keadilan dan sanksi hukum yang tidak ada kezaliman di dalamnya di satu sisi, dan manfaat di sisi lain merupakan makna-makna yang saling melengkapi dan mengikat satu sama lain yang dipersatukan oleh ikatan pemikiran yang kokoh dan kuat. Dengan demikian, tegas Abû Zahrah, manfaat dalam makna Islam sebagaimana dijelaskan dan makna-makna yang terkandung di dalamnya baik dari sisi rohani, intelektual maupun material sama sekali tidak mengandung kezaliman, bahkan ia merupakan keadilan yang sesungguhnya yang mungkin direalisasikan. ${ }^{57}$

Berdasarkan telaah mendalam terhadap hukum pidana Islam, ternyata keadilan merupakan tujuan hukum yang menjadi poros utama keseluruhan hukum-hukum Islam. Keadilan nampak sangat jelas pada seluruh bidang hukum Islam, tidak hanya pada hukum pidana Islam. Bahkan, keadilan menempati posisi tertinggi di antara tujuan hukum Islam lainnya. Hal itu disebabkan oleh sebab yang sederhana, yaitu karena hukum Islam terdiri dari perintah dan larangan. Masing-masing ada imbalannya. Sedangkan keadilan tidak dapat dilepaskan dari imbalan/balasan. Fuqahâ biasa menyatakan bahwa keadilan adalah soko guru hukum Islam (al-'adl 'imâd al-sharîab), sebagaimana taubîd adalah soko guru aqidah. Keadilan terpusat pada fitrah manusia. Karena itu, semua aturan perundang-undangan mengakuinya. Jika tubuh memiliki beberapa panca indera, maka akal juga demikian. Di

56 Ibid., 35.

${ }^{57}$ Ibid. 
antara indera akal adalah indera keadilan. Oleh karena itu, Islam sebagai agama fitrah, tentu saja ketetapan hukumnya lebih banyak yang sesuai dengan ide keadilan. ${ }^{58}$

Atas dasar itu, Abû Zahrah berpendapat bahwa aliran yang mendasarkan hukum pada asas perlindungan terhadap kemaslahatan manusia yang diakui sharî́ah Islam merupakan aliran praksis yang tepat, sebab ia merealisasikan penegakan prinsip-prinsip yang diakui dalam sharî‘ah Islam sekaligus menegakkan prinsip keadilan, meletakkan batas-batas untuk menolak tindakan berlebihan, dan menetapkan kesesuaian antara tindak pidana dan sanksi hukum atasnya. Menurut Abû Zahrah, teori utilitarianisme sebagaimana dicanangkan Jeremy Bentham tidak melepaskan sanksi hukum dari makna keadilan dalam rangka memberikan perlindungan bagi kemaslahatan manusia, akan tetapi justru menetapkan dan mengokohkan keadilan itu sendiri. Bentham menegaskan keniscayaan adanya kesesuaian antara tindakan pidana dan sanksi hukum. Adanya kesesuaian itu menjadikan sanksi hukum benar-benar hadir di dalam benak orang yang hendak melakukan tindak pidana dan cukup memengaruhi cara berpikirnya. Ketika pembuat undang-undang menetapkan sanksi hukum berangkat dari sifat dasar tindak pidana, maka keadilan telah ditegakkan dan hawa nafsu dikalahkan dalam penetapan sanksi hukum. Dalam hal ini sanksi hukum tidak datang dari pembuat undang-undang, akan tetapi berasal dari tindak pidana itu sendiri, sehingga seseorang tidak dihukum oleh saudaranya. ${ }^{5}$

Menurut Abû Zahrah, pengaruh yang ditimbulkan sanksi hukum harus disesuaikan dengan keadaan pelaku tindak pidana supaya hasil akhir dari sanksi hukum itu tidak lebih menyakitkan dibandingkan kerugian yang timbul dari tindak pidana yang dilakukannya terhadap masyarakat. Atas dasar itu, ia menyimpulkan bahwa teori utilitarianisme yang digagas Bentham merupakan asas yang kokoh dalam penetapan sanksi hukum, karena tindak pidana merupakan pelanggaran batas terhadap kemaslahatan manusia. Teori ini tidak dapat melepaskan diri dari prinsip keadilan. Ini berarti bahwa tahap akhir dari hukum pidana sangat sesuai dengan pendapat Bentham, karena ia mempertimbangkan kemaslahatan masyarakat sekaligus merealisasikan keadilan, yang berarti berada pada koridor teori

58 Muhammad 'Iwaḍ, Dirâsât fi al-Fiqh al-Jinâî́ (Kairo: Maktabat al-Shurûq alDawlîyah, 2010),187.

${ }^{59}$ Abû Zahrah, al-Jarimah, 36. 
Immanuel Kant bahwa keadilan sejati merupakan bagian dari kewajiban yang harus ditunaikan. Dua pandangan ini dalam praktiknya senada dan seirama. Ketika kewajiban ditunaikan dan keadilan ditegakkan, niscaya terwujud kemanfaatan umum yang sesungguhnya. Ketika manfaat ditunaikan dan dihormati, niscaya keadilan ditegakkan, baik didorong motivasi menegakkan keadilan sejati sebagaimana pendapat Kant maupun didorong motivasi mendapatkan manfaat untuk sebanyak mungkin orang sebagaimana pendapat Bentham.

Berkaitan dengan penetapan tindak pidana dalam sharî́ah Islam, Abû Zahrah menegaskan bahwa suatu tindakan dipandang sebagai tindak pidana manakala mengandung unsur melanggar maslahabmașlahah yang diakui sharî‘ah Islam berdasar al-Qur'ân dan Sunnah dan bahwa sanksi hukum terhadap tindak pidana harus mempertimbangkan sisi perlindungan terhadap ragam maslahah ini. Bahwa keadilan sejati yang mungkin dilakukan di dunia hanya dapat terealisir di dalam hukum Islam, yang menegaskan bahwa keadilan harus dipraktikkan seiring dengan perlindungan terhadap maslahabmaslaḅah sosial yang diakui sharî́ah Islam. Abû Zahrah menegaskan bahwa sharî‘'ah Islam telah menetapkan hal itu sebelum perundangundangan kontemporer lebih dari 12 abad yang lalu. Namun kembalinya pengetahuan ini ke dalam pangkuan bumi Islam merupakan salah satu bentuk penemuan barang hilang milik umat Islam.

\section{Penutup}

Abû Zahrah meminjam argumen yang biasa digunakan para filsuf utilitarianisme untuk mendukung maslahah sebagai metode istinbât hukum. Dalam menjelaskan arti maslaḥah, Zahrah seringkali mengutip pendapat dua filsuf etika Barat terkemuka, yaitu Jeremy Bentham dan John Stuart Mill. Menurutnya, ada titik temu antara sebagian fuqabâ yang menjadikan maslahah sebagai metode istinbat hukum dengan para filsuf utilitarianisme yang menjadikan manfaat sebagai tolok ukur moral. Bentham menggunakan kalkulus kepuasan secara kuantitatif untuk mengukur manfaat dan kerugian. Menurutnya, ada tujuh faktor yang menentukan berapa banyak kepuasan dan kepedihan yang timbul dari suatu tindakan yaitu intensitas, durasi, kepastian, kedekatan, kesuburan, kemurnian, dan jangkauan. Perhitungan akan menghasilkan saldo positif jika kredit (kepuasan) melebihi debetnya (kepedihan). 
Ketika melakukan istinbât hukum menggunakan metode maslahah, Abû Zahrah meminjam pendapat Bentham dan Mill sebagai kesatuan untuk mengukur maslahah dan mafsadah. Dari Bentham, ia mengambil kalkulasi maslahab bahwa tindakan yang seharusnya diambil adalah tindakan yang dinilai memiliki kadar manfaat terbesar untuk sebanyak mungkin orang dengan jangka waktu paling lama (adwamubâ). Abû Zahrah seringkali menggunakan tiga parameter di atas, meskipun, sebenarnya ada tujuh parameter untuk mengalkulasi kepuasan tindakan menurut Bentham.

Dari Mill, Abû Zahrah meminjam pandangannya yang membagi kepuasaan menjadi dua yaitu kepuasan menjadi dua yaitu kepuasan yang bersifat material dan spiritual serta menempatkan kepuasaan spiritual di atas kepuasaan material. Kemudian Abû Zahrah membagi maslahah menjadi dua yaitu maslahah masa kini dan maslaḥah masa mendatang yang mana ia lebih mendahulukan yang tersebut kedua daripada yang pertama. Dalam penerapannya terhadap kasus-kasus hukum yang ditangani berdasar kalkulasi maslahah bahwa Abû Zahrah lebih setuju pada pendapat Mill daripada Bentham, meskipun ide besarnya tetap diambil dari Bentham khususnya berkaitan dengan prinsip The Greatest Happiness for the Greatest Number.

Di antara kaidah penting yang merupakan temuan Abû Zahrah dalam khazanah al-qawâiid al-fiqbîyah adalah kaidah yang disimpulkannya dari filsafat utilitarianisme yaitu kaidah maslahah atau manfaat sebesar mungkin bagi sebanyak mungkin orang dan kaidah bahwa kerugian yang yang harus dihindarkan adalah kerugian sebesar mungkin terhadap sebanyak mungkin orang.

\section{Daftar Rujukan}

Abû Zahrah, Muhammad. al-Jarimah wa al-'Uquibah fì al-Fiqh al-Islâmî: Jarimah. Kairo: Dâr al-Fikr al-'Arabî, t.th.

-----. al-Mujtama' al-Insânî fî Zill al-Islâm. Kairo: Dâr al-Fikr al-'Arabî, t.th.

----. Mâlik: Hayâtuh wa 'Așruh, Ârâuh wa Fiqhuh. Kairo: Dâr al-Fikr al'Arabî, t.th.

----. Târîkh al-Madhâhib al-Islâmîyah. Kairo: Dâr al-Fikr al-'Arabî, 2009.

----. Ușûl al-Figh. Kairo: Dâr al-Fikr al-'Arabî, t.th.

Bentham, Jeremy. An Introduction to The Principles of Morals and Legislation. Kitchener: Batoche Books, 2000. 
Bûțî (al), Muhammad Sa îd Ramadân. Dawâbit al-Maslahah fì al-Sharîah al-Islâmîyah. Damaskus: Dâr al-Fikr, 2005.

Gaarder, Jostein. Shopie's World, terj. Rahmani Astuti. Bandung: Mizan, 2012.

Hallaq, Wael. B. Was The Gate of Ijtihad Closed?. New York: International of Middle East Studies, 16, I, 1994.

'Iwaḍ, Muḥammad. Dirâsât fi al-Fiqh al-Jinầî. Kairo: Maktabat alShurûq al-Dawlîyah, 2010.

Jawzîyah (al), Ibn Qayyim. Miftâh Dâr al-Sa'âdah wa Manshûr Wilâyat alIlm wa al-Irâdah. Beirut: Dâr al-Kutub al-'Ilmîyah, 1998.

Mill, John Stuart. Utilitarianism. New York: McGraw Hill, 2001.

Nasution, Harun. Islam Rasional. Bandung: Mizan, 2000.

-----. Pembaharuan dalam Islam Islam: Sejarah Pemikiran dan Gerakan. Jakarta: Bulan Bintang, 1975.

Râzî̀ (al), Fakhr al-Dîn. al-Maḥ̣̂ul fî̀ Ilm Ușûl al-Fiqh, Vol. 6. Beirut: Muassasat al-Risâlah, 1998.

Razzâq (al), Abû Bakr 'Abd. Abû Zahrah Imâm 'Asrib: Hayâtuh wa 'Atharub al-Tlmî. Kairo: Dâr al-I'tișâm, 1984.

Salâm (al), 'Izz al-Dîn b. 'Abd. Qawâiid Aḅkâm fi Islâh al-Anâm. Damaskus: Dâr al-Qalam, t.th.

Shâtịî (al), Abû Ishậq Ibrâhîm b. Mûsa. al-Muwâfaqât fì Ușûl alSharîah, Vol. 1. Saudi Arabia: Dâr Ibn 'Affân, 1997.

Suyûtûi (al), Jalâl al-Dîn. al-Asbbâh wa al-Naz̧âir fî al-Furû'. Surabaya: alHidâyah, t.th.

Tûufi (al), Najm al-Dîn. Risâlah fì Ríâyat al-Maslahah. Beirut: Dâr alMaṣdarîyah al-Lubnânîyah, 1993.

Waḥdân, Nâșir Maḥmûd. Abûu Zahrah 'Aliman Islâmiyyan. Kairo: Dâr al-Haram li-al-Turâth, 2012. 